\title{
Nuclear Factor Interleukin-3-Regulated Protein
}

National Cancer Institute

\section{Source}

National Cancer Institute. Nuclear Factor Interleukin-3-Regulated Protein. NCI

Thesaurus. Code C84454.

Nuclear factor interleukin-3-regulated protein (462 aa, $\sim 51 \mathrm{kDa}$ ) is encoded by the human NFIL3 gene. This protein plays a role in the modulation of transcription. 